\title{
Mithradates I AND the BeginNing of THE RUlER-CUlt IN PARTHIA*
}

Hellenistic monarchies developed at one time or another a characteristic trait which was a cult of the ruler. It reflected tendencies arising in the Hellenistic period's social, political, and religious life. Some rulers used it to try to build ideological and political unity in the societies they ruled. Owing to its universal character, such a cult could be useful in building and maintaining emotional and political bonds between subjects and the current reigning monarch, as well as in reinforcing their loyalty toward the dynasty he represented. In the Greek world, religious worship of the king first took place under Alexander of Macedon, although the practice did not prove too popular at the time. It only gained wider currency during the reigns of his successors, to become widespread in the $2^{\text {nd }}$ century B.C. ${ }^{1}$ The growth of the cult of the king in the Hellenistic world was not always administered by the ruler himself. Often such worship was initiated and maintained by subjects out of a desire either to express their special gratitude for his favors and his care (typically in the face of external threats or national disasters) or to ensure his favor in the future. ${ }^{2}$

The ruler-cult in the Hellenistic world took on many forms. Also, religious practices involved varied considerably. The most outwardly visible expressions of such worship were temples built and dedicated to him, complete with priestly colleges created to serve in them and appropriate rituals designed. ${ }^{3}$ Accordingly, organization of the ruler-cult varied in form between or among respective monarchies. The cult could be nation-wide, supervised by the king himself, who created appropriate institutions and appointed priests ${ }^{4}$, or it could be local, especially when limited to respective cities. ${ }^{5}$ Each Hellenistic dynasty created its own model for its cult to be practiced. Important differences

* I would like to acknowledge the assistance of Professor Henry I. MacAdam with revision and correction of the English of this paper. Any errors of fact or interpretation remain strictly my own.

1 See Habicht 1956; Chaniotis 2004: 544 ff.; Schmitt 2005: 444 ff.

2 Cf. Bickermann 1938: 256-257; Chaniotis 2004: 550-551.

3 Cf. Schmitt 2005: 449.

4 Cf. Bickermann 1938: 247 ff.

5 Bickermann 1938: 242 ff.; Chaniotis 2004: 550 ff. 
between such models are clearly discernible, for instance, between the respective forms of worship in the Ptolemaic state and in the Seleucid empire. ${ }^{6}$

Even though much has been written on the Seleucid Empire's ruler-cult, our knowledge of its organization and functioning is still rather limited by the shortage of extant historical sources on the subject. Outside the western provinces of their state, this cult gained some popularity in Mesopotamia and other eastern lands, at least among those subjects who were of Greek or Macedonian descent or had become Hellenized. ${ }^{7}$ Its practice is confirmed by epigraphic evidence and cuneiform texts. ${ }^{8}$ Unfortunately, such evidence contains no clear proof for religious worship conducted in such areas to kings under the then ruling Parthians. Scholars are far from agreement about this matter. Prevailing opinions hold that if the Arsacids professed Zoroastrianism, which rules out the worship of men, it seems unlikely that a ruler-cult (as that known in the Hellenistic world) would apply to their state. ${ }^{9}$ Yet certain indications may help question this belief. ${ }^{10}$ These have recently been supplied especially by archaeological excavations in Old Nisa, and also by the study of Arsacid coinage and Hellenistic royal titulature.

Inquiry into the matter of whether the Arsacids were the object of religious worship must begin with an analysis of existing findings from the Old Nisa excavations. ${ }^{11}$ It is thought that the origins of Old Nisa go back to the time the Parthian state was being created. It is also thought that in the latter half of the $3^{\text {rd }}$ century B.C. the Parthians erected there a powerful fortress which also made a residence for the Arsacids. In the course of the $2^{\text {nd }}$ century B.C., the role of Old Nisa changed dramatically, most likely associated with its being renamed as Mithradatkert ("Mithradates' fortress") (cf. Diakonoff/Livshits 2001, no. 2624). The change was in transforming the city from a royal residence into a religious center devoted to fostering the cult of the ruling dynasty. ${ }^{12}$ Archaeological evidence suggests that such change in character into a center of Ar-

${ }^{6}$ See Bickermann 1938: 236-257; Sherwin-White/Kuhrt 1993: 202 ff.; Debord 2003: 281 ff.; Chaniotis 2004: 547-548, 551 ff.; Schmitt 2005: 447-448; Pfeiffer 2008.

${ }^{7}$ Cuneiform texts from Mesopotamia suggest that the native population might have attended sacrificial celebrations in temples on behalf of the king (cf. Sherwin-White/Kuhrt 1993: 202 ff.), but most probably did not take part in other forms of ruler-cult: Linssen 2004: 124-128; Clancier 2007: 38 ff.; Pirngruber 2009.

${ }^{8}$ Cf. Hopkins 1960/1961: 237 ff.

${ }^{9}$ Gariboldi 2004: 371 and note 46. Cf. Pilipko 2000: 104 ff.

${ }^{10}$ Facts relating to ruler-cult among the Parthians are sometimes explained through the lens of Iranian traditions not necessarily closely connected with Zoroastrianism, cf. Wiesehöfer 1996: 62; 2000: 712; Muccioli 2009.

${ }^{11}$ As excavations continue, the present state of research is emphasized here. It cannot be ruled out that the present findings may in future be verified or added to. One question disputed from the beginning of research into Old Nisa is its identification with what Isidore of Charax (Stath. Parth. 12) calls Parthaunisa, where he said an Arsacid necropolis was to have been located. While such identification had been taken for granted before the archaeological excavations began, the discovery of an ostracon which features another name for Old Nisa, Mithradatkert, threw it into question: Pilipko 2000: 99 ff., 109; 2006: 53; 2008: 33-34. A different position on the matter is taken by A. Invernizzi (2004: $133 \mathrm{ff}$.), in whose opinion (p. 137), “...the evaluation of the evidence available today, with all its uncertainties, does not prove but does not seem to raise serious obstacles against the identification of the Parthaunisa/Nisaia of Isidorus with Nisa, and specifically with New Nisa, in the eastern suburbs of which Mithradates I founded the birtha of Mithradatkert, or Old Nisa.)".

12 According to M.-L. Chaumont (1973: 215) - an opinion voiced before archaeological work in Nisa had been advanced enough for experts to be able to identify individual structures - Old Nisa was at once the Arsacids' royal residence and necropolis until the $1^{\text {st }}-2^{\text {nd }}$ centuries A.D. 
sacid dynastic propaganda gave Old Nisa a fresh impulse for development, assuring it prosperity lasting until the $1^{\text {st }}$ century A.D. During that time, buildings erected to serve the cult, which made up its Central Ensemble, underwent many modifications, which, however, did not apply to strictly religious facilities. In the form known to us today, such facilities were built already at an early stage in the creation of the Ensemble. ${ }^{13}$ Although the exact chronology of Old Nisa's architectonic development remains disputable, most scholars agree in supposing that the ruler who helped transform Old Nisa into a cult center was most likely Mithradates I. ${ }^{14}$

The religious nature of structures in Old Nisa which made up the Central Ensemble was never in question. ${ }^{15}$ The progress in archaeological work has fully borne out this belief. The compound's very architecture rules out its functions as a residence, as the floor plans of two of its structures, the Round Hall Building and the Square Hall Building unmistakably reveal their function as places of worship. Both are considered central to the whole complex. ${ }^{16}$ In the earlier, the interior was a circular space $17 \mathrm{~m}$ in diameter only accessible from the outside via three narrow aisles. ${ }^{17}$ It was specially designed for its purpose, as is suggested by its shape closely resembling a Greek tholos. As to the Round Hall, scholars disagree not only about the height of its interior - whether it was single- or multistory - but also whether it was topped with a brick cupola or a wooden roof. ${ }^{18}$ Proposed reconstructions prompt different interpretations of its role. Because of some excavated fragments of terracotta figures, some scholars see it as a gallery of Parthian kings and their mythical ancestors which would serve both religious cult and dynastic propaganda at the same time. According to one hypothesis, the Round Hall was a dynastic mausoleum of the Arsacids. This interpretation of the building would be backed not only by its architecture, but also by an account saying that Nisa was the burial place of Parthian kings. ${ }^{19}$ Yet the findings of the archaeological work done so far have not supplied any evidence to confirm the sepulchral nature of the building. ${ }^{20}$ In

13 The history of Old Nisa can only be traced based on evidence from archaeological excavations; only to a small extent is information helpful which was obtained from ostraca discovered there: Lippolis in Invernizzi/Lippolis 2008: $369 \mathrm{ff}$.

14 Cf. Invernizzi 2001a: 147; 2001b: 308-309; 2004: 137, 139; Lippolis 2006: 62; Pilipko 2006: 54; Lippolis in Invernizzi/Lippolis 2008: 369-370; Lippolis 2009. A connection between the constructions of this center with this particular king may be indirectly suggested by an ostracon dated to the $2^{\text {nd }}$ century B.C. found in Old Nisa (cf. Diakonoff/Livshits 2001: no. 2624): Invernizzi 2004: 135-136; Pilipko 2008: 46. Not all scholars share this view, cf. Chaumont 1973: 214-215.

15 Cf. Pilipko 2000: $103 \mathrm{ff}$. The complex consists of a total of more than ten buildings of different shape and size. Thanks to archaeological excavations begun in the late 1930's and, with varying intensity, continuing till today, all of its parts have been uncovered. With the knowledge thus gained, it is now possible to identify the probable functions of respective buildings and to trace changes in their architecture. For a synthetic description of the entire complex, together with a summary of the existing state of knowledge about its layout, historical development, and functions in worship, see Invernizzi 2001b: 302 ff.; Pilipko 2006: 53 ff.; 2008: 33-51; Lippolis in Invernizzi/Lippolis 2008: 7 ff., 371 ff.

16 Excavations on the premises of the Southwest Building (a structure referred to in archaeological reports by an Italian expedition as Edificio Rosso for the color of wall decorations found there) now help identify it, too, as worship-related, cf. Lippolis 2006: 62 ff.; Lippolis in Invernizzi/Lippolis 2008: 83-149; Lippolis 2009.

17 Lippolis 2006: 59 ff.; Pilipko 2008: 40-41; Masturzo in Invernizzi/Lippolis 2008: 43-64.

18 See Blasi/Coïsson/Ferretti in Invernizzi/Lippolis 2008: 66-80; Pilipko 2008: 40-41.

19 Isid., Stath. Parth. 12; cf. Invernizzi 2001b: 310.

20 Pilipko 2008: 48-49. Cf. Invernizzi 2004: 138-139. 
another hypothesis, the Round Hall was a herôon, a building serving the cult of Mithradates I or his dynasty's mythical ancestors, yet not in any way related to actual burials. ${ }^{21}$ Also the Square Hall, so named for the shape of its interior, revealed remnants of figures in what is a gallery of unidentified persons. ${ }^{22}$

The ground plan of the Central Ensemble, as well as the architecture of respective buildings in it, permits some speculation about the nature of the religious ceremonies held there and the numbers of people involved. A spacious, open Central Courtyard and adjoining covered spaces within the Northeast Building could hold large congregations. Most participants had no access to strictly religious facilities. Some forms of worship were probably restricted to a privileged few, perhaps members of the ruling family, high officials at the court, or members of the aristocracy. The layout of the entire compound may imply that all those present in the yards joined in common prayers, while the privileged could participate in symposia (gatherings popular in the ruler-cults in the Hellenistic world) combined with prayers in the Northeast Building. ${ }^{23}$ Perhaps it is with some religious practices that we should associate the ivory rhytons discovered in great numbers in Old Nisa. ${ }^{24}$

Archaeological excavations supply no evidence to suggest any links between the Old Nisa religious center and Zoroastrian rituals. In its character, it clearly departs from various cult-related structures known from other parts of the Iranian world. ${ }^{25}$ Its construction and then its use for Arsacid dynastic propaganda suggests that whoever built this compound was trying to establish a religious-based ideological program in which

21 Invernizzi 2001b: 309; 2004: 137 ff., esp. 139; Lippolis in Invernizzi/Lippolis 2008: 382. Fragments of terracotta figures found in the Round Hall speak in favor of this interpretation since - regardless of the architecture of the building alone - the presence of such figures may settle the question of its religious function. Whether they represented members of the dynasty, mythological ancestors, or both, they were an indispensable prop for religious practices. At the present stage of research (despite our ability to make comparisons with Arsacid iconography as seen on coins), what with their fragmentary state of preservation, it is difficult to decide whom they represented. According to A. Invernizzi (2001a: 141 ff., esp. 143-147; 2001b: 308-309; cf. Bollati in Invernizzi/Lippolis 2008: 192), one fragment may be part of a statue of Mithradates I. Not all scholars agree with this view, cf. Pilipko 2008: 48. Other, better preserved figures were discovered in the Square Hall Building. Their style shows more Greek than Parthian elements, and the figures are devoid of any kingly attributes. Even so, it is still not impossible that they were somehow involved in the Parthian dynastic cult: Pilipko 2000: 107-108; Invernizzi 2001a: 147 ff.; Invernizzi 2001b: 306 ("It is likely that the statues of the Square Hall did not represent gods but figures in some way connected with Arsacid history.”); Pilipko 2008: 48; cf. Bollati in Invernizzi/Lippolis 2008: 191 ff. Hypotheses concerning the nature and function of the buildings comprising the Central Ensemble are discussed by: Pilipko 2000: 107 ff.; 2008: 47 ff.; Lippolis in Invernizzi/Lippolis 2008: 365-384.

22 Pilipko 1996: 51-63. See also above note 21.

23 Pilipko 2006: 56-57; 2008: 49-50.

24 According to A. Invernizzi (2001b: 300-301), they might have been used in symposia held in the king's presence in the Square House, in the northern part of the citadel, in whose ruins they were discovered. Yet the place of discovery does not rule out their connection with cultic practices performed in the Central Ensemble. Later in its history, the Square House was probably used as storage space: Pilipko 2000: 100-102.

25 Pilipko 2000: 110. Even though the architecture of the Central Ensemble shows no Zoroastrian influences, A. Bader (1996: 273 ff.) believes them to be discernibly present in the anthroponomy of Old Nisa's inhabitants whose names have been preserved on ostraca found there. Such influences are also confirmed by the calendar in use there. Bader (1996: 272) adds: "In principle, the cult of Zoroastrian gods could coexist in Nisa with the post mortem cult of the dead members of the Arsacid royal family". But he nevertheless admits (p. 273): “The problem of the post mortem cult of the Arsacid kings is still unclear”. 
an important part was to be played by the dynastic cult. This is further confirmed by the public nature of the celebrations held in Old Nisa which were designed to imprint in social awareness the political and religious aspects of Arsacid rule, forging them into one.

Each Hellenistic dynasty promoted its own dynastic ideology, using for this purpose a whole array of personages who had stood out in its history and building a set of symbols easily identifiable to subjects. Religious practices involved in the ruler-cult made for an element of propaganda. Organized forms of such cult helped not only build subjects' loyalty to the king, but also forge them into a community to function on a common foundation of shared ideological values. Dynastic themes in Hellenistic ruler-cults ensured continuity of political tradition, which proved crucial when struggles between pretenders, or usurpations, led to all too frequent replacements on the throne.

A key question about the Old Nisa compound concerns its time of creation. Although the city has now long been the site of excavations, no evidence has so far been found to help answer that question with any confidence. All that has been learned only implies, as has been mentioned, that the compound might have been built already under Mithradates I. It seems that the dispute over this matter may benefit from considering numismatic evidence.

A study of the coinage of the first Arsacids clearly reveals that the reign of Mithradates I constituted an important milestone. Early in his reign, his coins did not differ much from those issued by his predecessors. However, some time later, Mithradates I's issues began to feature compound legends. Compared to his predecessors' coinage, in which the legends comprised only the king's name and royal title, that was a major change. Without a doubt, any additions to Mithradates I's titulature were designed to emphasize selected elements of his public image, those he considered especially worth being appreciated. Such changes did not last. Introduction of another title on coin was by no means considered permanent. In each new issue, the new title could be omitted or replaced. ${ }^{26}$ Such was the case, e.g., with the title $\Theta E O \Pi A T \Omega P$ ("Son of a Deified Father”), which Mithradates used for the first time among Parthian kings. The title appears only on coins in the unique issue produced in Hecatompylos, many years after he became king. ${ }^{27}$ Although the Hellenistic world frequently saw deification of rulers, public emphasis on their own divine descent was never a common occurrence. ${ }^{28}$ It is unknown why Mithradates I chose to use this unusual appellation. In trying to explain it, one more important piece of evidence should be considered: the drachm S 10.15, also from the Hecatompylos mint, on which the Parthian king's standard portrait and title is accompanied by the title $\Theta \mathrm{EO} \Sigma$ (the "god"). Based on the coin’s properties such as iconography and legend, scholars agree in ascribing the

26 Cf. Dąbrowa 2008: 23-24.

27 S 10.17 = Trit. VII, 400. According to G.R.F. Assar (Trit. VII, p. 110, and p. 111 (commentary to no. 400), the coin should be attributed to Phraates I. Gariboldi (2004: 374-375) cites previous attribution by G. Le Rider ascribing it to Phraates II.

28 This remark refers chiefly to coinage. Outside the Arsacid dynasty, the only known instance of a Hellenistic king using the title $\Theta E O П A T \Omega P$ was Alexander Balas. He was a usurper outside the Seleucid family circle who used the support of Ptolemy VI, the king of Egypt, to capture the Syrian throne. He used the title to justify his claim to the throne. It was meant as a confirmation of his descent from Antiochus IV Epiphanes, whose son he claimed to be: Gariboldi 2004: 368 ff. 
piece to Mithradates I. ${ }^{29}$ Such attribution seems to imply that among the Arsacids, it was he who first claimed divinity. Contrary to appearances, this conclusion is not contradicted by his use of the appellation $\Theta \mathrm{EOПАТ \Omega P} \mathrm{next} \mathrm{to} \mathrm{his} \mathrm{name} \mathrm{on} \mathrm{the} \mathrm{above-}$ -mentioned coin S 10.17. ${ }^{30}$ It might simply mean that Mithradates I deified his father precisely to serve the needs of his own propaganda. Therefore, the title $\mathrm{\Theta EO} \Sigma$ on coin S 10.15 does not necessitate attributing it to Phriapitius. ${ }^{31}$ Instead, it is plausible to assume that the title was used by Mithradates I himself. ${ }^{32}$ To some extent, Mithradates I's self-deification is confirmed by how his sons and successors used the title $\Theta \mathrm{EO \Pi АT \Omega P.}{ }^{33}$ It must be said that there is no contradiction between the king using a title proclaiming his divinity and another his divine descent. ${ }^{34}$ Among Mithradates I's successors, such practice became the norm.

Mithradates I's deification of Phriapitius brings up a question about his purpose in so doing. Of Phriapitius, as of Phraates I (his son and brother of Mithradates I) we know no more than that both helped expand and consolidate their state. ${ }^{35}$ What with the constant Seleucid threat and the weakness of their state administration, they probably had little chance to develop in their subjects a lasting awareness of any traditions involving a mythical predecessor or founder of the dynasty. ${ }^{36}$ What is unquestionable is that the credit for transforming the Parthian state into an empire goes to Mithradates I. His conquest of territories inhabited by peoples of diverse social traditions, cultures, religions, and even economies at some point made him face challenges unknown to his predecessors. Ruling a country that size required him to find a unifying common ideological denominator. That role could be served, as in other Hellenistic states, by a rulercult. In order for the cult to take root, it was necessary to develop a dynastic tradition. It was in such circumstances that Mithradates I might have decided - to further his case - on a posthumous deification of his own father. Similar instances of dead kings being idolatrized are known from Hellenistic monarchies and Rome.

In our context, it would be desirable to define the time Mithradates I sanctified himself as it would give us a better estimation of its importance. Especially helpful in this respect can be the king's coinage. ${ }^{37}$ For chronological reasons, the breakthrough point in this coinage was the above-mentioned alteration in style and iconography. It was

\footnotetext{
${ }^{29}$ Sellwood 1980; cf. Assar 2005: 45.

${ }^{30}$ Cf. Assar 2004: 88; 2005: 45.

31 G.R.F. Assar (2004: 82, 88; 2005: 38; Trit. VII, p. 110) believes that the coin was issued by Phriapitius, which would make him the first Arsacid to bear the title.

${ }^{32}$ Cf. Gariboldi 2004: 375.

33 The title $\Theta Е О П А Т \Omega P$ was used by his sons: Phraates II, his immediate successor (S 16.1-30), and Artabanus I (S 19.1-2).

34 The title $\Theta E O \Sigma$ was not the only one to have been used by the Arsacids to emphasize their divine status. It is probable that they used the appellative ЕПIФANH $\Sigma$ in the same sense. This author intends to address this issue in some separate remarks. With Mithradates I's successors such practice became the

35 Cf. Isid. Stath. Parth. 7; Iust. 41.5.8-9; Karras-Klapproth 1988: 131-132, 152-153; Assar 2004: 87-88.

${ }^{36}$ Contrary to what is suggested in the account by Ammianus Marcellinus (23.6.6), Arsaces I did not live to become formally deified, cf. Drijvers 1999: 198-199.

${ }^{37}$ Up until the time of Mithradates I, Parthian coin issues bore no dates. These only appeared on some coins from Seleucia on the Tigris, struck after it was captured in 141 B.C.: S 13.3-5 (tetradrachms); 13.8-10 (drachms).
} norm. 
marked by the appearance on the obverses of coins minted throughout the Parthian kingdom of a new-type portrait of the ruler with individualized facial features, and stylistically akin to Seleucid portraits. The image first appeared on coins designated type S 11 which were produced in mints in Hecatompylos ${ }^{38}$ and Nisa. ${ }^{39}$ Interestingly, the new portrait type was first put on coins struck in mints located in the original Parthian territories. This goes to suggest that its introduction had no direct relation to Mithradates I’s expansion into territories inhabited by Greek populations. However, a clearer link with it can be seen in the following coin set (S 12) of various denominations, produced mainly in Ecbatana, Rhagae, and Susa, on whose obverses the king's head faces right, as was the practice in Seleucid coinage. The link is suggested by the fact that coins of this type come exclusively from mints in Media and Elymais. The earlier land had been conquered by Mithradates I probably shortly after 148 B.C. ${ }^{40}$, and Elymais after 141 B.C. ${ }^{41}$ These dates, then, define the approximate terminus post quem of their issue. A third coin series with the new likeness of the king (S 13) was struck only in Seleucia on the Tigris after the city had been taken in July 141 B.C. ${ }^{42}$

The above remarks suggest that the appellations $\Theta \mathrm{EO} \Sigma$ and $\Theta \mathrm{EO \Pi AT \Omega P} \mathrm{appear}$ solely on those coin series that were minted directly prior to the annexation of Media and Mesopotamia. This means that Mithradates I's deification of Phriapitius and promotion of his own divinity preceded his great conquests. It is noteworthy that both issues in question came from the Hecatompylos mint. They were therefore not intended for Parthia's newly subjugated Greek subjects, but rather for inhabitants of lands already long under the Arsacid scepter. Promoting the ruler's sacred status and the divinity of the dynasty of which he was a member was thus to bestow a religious dimension on the ruling Arsacids in the awareness of their "old" subjects. ${ }^{43}$ Based on available sources, we cannot be sure that Mithradates I changed the name of Old Nisa to Mithradatkert;

38 S 11.1-2 (drachms); 11.5 (obol); 11.6-7 (chalkos).

39 S 11.3-4 (drachms). On their obverse, the profile of Mithradates I faces left. The reverse shows an archer sitting on an omphalos.

40 The exact date of the definite conquest of Media is unknown. It is defined based on the dating of an inscription on a statue of Heracles in Bisutun carved by Cleomenes, a Syrian governor of Media (Jun/Jul. 148): Robert 1963: 76; 1967: 283, 291; Luschey 1974: 122-123, 125, fig. 16; Assar 2005: 42-43. Conquering Media was a process that took Mithradates I many years during which he gradually occupied its successive territories, cf. Iust. 41.6.6-7; Dąbrowa 2006: 38.

41 Cf. Iust. 41.6.7. Justin's account suggests that the attack on Elymais took place soon after Media was conquered. In reality, it happened only after Mesopotamia had been dominated: Sachs-Hunger 1996: no.-140C, Obv., ll. 37ff. Despite an initial victory, Elymais had not been totally subdued until 125 B.C. during the reign of Artabanus I: Sachs-Hunger 1996: no. -124B: 'Obv.', l. 19; 'Obv.', ll. 13’-19'. For more on the situation in Mesopotamia and neighboring lands after 141 B.C., see Dąbrowa 2005: 73 ff.; Assar 2006: $91 \mathrm{ff}$.

42 It comprises two denominations: S 13.1-5 (tetradrachms); 13.6-10 (drachms). Their reverses repeat types of imagery known from the Seleucid period. Preserving the traditional reverse iconography was intended by Mithradates I as one of the steps he took to win the sympathy of Greek inhabitants of Seleucia. Some of his successors took a similar stance. From the reign of Mithradates II, it became the rule to feature an archer on reverses of tetradrachms produced in Seleucia on the Tigris (S 24).

43 This conclusion is in clear opposition to A. Gariboldi's (2004: 377 note 46) claim: "We cannot exclude, in fact, the possibility that the title of $\Theta \varepsilon$ ó $\varsigma$ and that of $\Theta \varepsilon o \pi \alpha ́ \tau \omega \rho$, actually were propagandistic devices targeting the Greek cities and peoples, but which did not affect the core of the Parthian royal ideology". 
however, the hypothesis cannot easily be dismissed that the change reflected the city being converted to a center of worship. ${ }^{44}$

One can hardly miss the propaganda message of both issues, even if their unique nature limited the extent of their impact. ${ }^{45}$ Without a doubt, Mithradates I's claim to divine status for himself and his dynasty was of great political import for him. In our opinion, his actions in this respect directly involved the creation of the religious complex in Old Nisa. Proclaiming the divine descent of the ruling dynasty, and propagating and reinforcing it in public awareness made it necessary to give the new cult an organized form and to provide a venue specifically devoted to such practice. That the deification of members of the Arsacid dynasty and creation of the religious complex in Old Nisa might have been components of Mithradates I's clearly defined ideological program is further indicated by his introduction in his empire of a calendar based on the so-called Arsacid era ${ }^{46}$ and, later in his life, his use of the title "king of kings." ${ }^{, 77}$ It is difficult to overlook the propaganda impact of all such measures in lending splendor and prestige both to the king and to his dynasty.

Based on available sources, we cannot be certain whether religious practices involved in the ruler-cult, as had been the case in the Seleucid empire, also took place in other centers of the Parthian empire. Nor do we know if the ruler-cult there had its own priests, if it varied in forms of worship, if observance was common or mandatory according to some established religious calendar, or what was the theological content of the worship. ${ }^{48}$ Similarly, we cannot determine exactly from what sources its respective elements originated. Although Hellenistic inspirations in the ruler-cult introduced by Mithradates I seem certain, the question remains open of where they had come from. Two possible sources of inspiration should be considered: the Seleucid state and the Greco-Bactrian state. Since the ruler-cult in the Seleucid Empire was introduced only under Antiochus III, and the Seleucids exerted limited influence in the satrapies the Parthians conquered early in their expansion, it seems that Syrian models could not

${ }^{44}$ Not impossibly, making Old Nisa a center of the Arsacids' dynastic cult led to the final establishment of a tradition concerning Arsaces I, the dynasty's founder. Accounts (Iust. 41.5.5-6; Amm. Marc. 23.6.2-6; cf. Strabo 16.1.28 [749]) speak of a great respect the Parthians showed to Arsaces I, which may imply that an official tradition was in place which helped preserve his memory. It seems only natural to give credit for its creation to Mithradates I as he was eager to build a dynastic ideology. For more on Arsaces I and traditions connected with his name, see Wolski 1937: 492-513; 1938: 244-266 (= Wolski 1974: 159-199); 1959: 222-238; Karras-Klapproth 1988: 18-22; Gaslain 2005: 9-30; Gaslain 2009.

45 Although until the end of Mithradates I's reign no other coin issue was released which would directly refer to his divinity, it is an insufficient argument to claim that the king's divine status was not quite as important as is here suggested. It was an accepted practice in the Arsacid state that titles referring to its respective kings' divinity only appeared on some of their monetary issues. Also, not all mints followed the same schedule in their introduction.

${ }^{46}$ There is no evidence to suggest that this era was in use during his predecessors' reigns: Assar 2003: 176.

${ }^{47}$ It is difficult to determine whether Mithradates I's adoption of the title was formal as it finds no reflection in coinage. Nonetheless, cuneiform texts confirm that the title was indeed in use: Sachs-Hunger 1996: no.-140C, Upper edge 1; Del Monte 1997: 245.

${ }^{48}$ Such content is rendered impossible to determine due to a lack of written records and an insufficient number of artifacts involved in worship. It is also the cause of some disagreement among scholars as to the nature of the cult: whether it simply copied models borrowed from the Hellenistic world or whether it included original theological themes, cf. Muccioli 2009. 
have significantly influenced Mithradates I's choices. If so, then it is possible that for his own purposes he used those elements of the ruler-cult which he might have encountered while fighting in Bactria. ${ }^{49}$ That some form of such worship existed in that state is confirmed by the titles its kings used. It was probably only after the conquest of Media and Mesopotamia that Mithradates I might have adapted for his own purposes more of Seleucid traditions relating to the ruler-cult. ${ }^{50}$ Perhaps further excavations in Old Nisa or other sites will supply evidence to clarify this matter. In the light of known facts, there is no doubt that the ruler-cult in the Parthian state began fairly early and that Mithradates I was particularly instrumental in establishing it.

\section{AbBreviations}

S - Prefix to the types of Parthian coins in Sellwood 1980.

Trit. - Triton. Auction Catalogue of Classical Numismatic Group, Inc., Lancaster-London.

\section{BIBLIOGRAPHY}

Assar, G.R.F. (2003): Parthian Calendars at Babylon and Seleucia-on-the-Tigris, Iran 41: 171-191. Assar, G.R.F. (2004): Genealogy and Coinage of the Early Parthian Rulers - I, Parthica 6: 69-93. Assar, G.R.F. (2005): Genealogy and Coinage of the Early Parthian Rulers - II: A Revised Stemma, Parthica 7: 29-63.

Assar, G.R.F. (2006): A Revised Parthian Chronology of the Period 165-91 B.C., Electrum 11: 87-158.

Bader, A. (1996): Parthian Ostraca from Nisa: Some Historical Data, in La Persia e l'Asia Centrale da Alessandro al X secolo, (Atti dei Convegni Lincei, 127), Roma: 251-276.

Bickermann, E. (1938): Institutions des Séleucides, Paris.

Boperachchi, O. (1991): Monnaies gréco-bactriennes et indo-grecques. Catalogue raisonné, Paris.

Chaniotis, A. (2004): La divinité des souverains hellénistiques, in A. Erskine (ed.), Le Monde hellénistique. Espaces, sociétés, cultures 323-31 av. J.-C., Rennes: 541-556.

Chaumont, M.-L. (1973): Études d'histoire parthe, II: Capitales et residences des premiers Arsacides (III ${ }^{\mathrm{e}} \mathrm{I}^{\mathrm{er}}$ s. av. J.-C.), Syria 70: 197-222.

Clancier, Ph. (2007): La Babylonie hellénistique. Aperçu d’histoire politique et culturelle, Topoi 15: 21-74.

${ }^{49}$ Cf. Iust. 41.6.1-3; Strabo 11.9.2 [515]; 11.11.2 [516-517]; Rtveladze 1995: 183 ff.; Assar 2004: 82; Dąbrowa 2006: 38. During the time Mithradates I fought Bactrian kings, their state did have a ruler-cult. This is confirmed by legends on coins they issued, cf. Boperachchi 1991: 59 ff., 178-179, Ser. 14-15 (Agatholes for Diodotus Theos); 183 ff., Ser. 1-4; 187, Ser. 9-10 (Antimachus Theos).

50 Cf. Invernizzi 2004: 140. 
Dąbrowa, E. (2005): Les aspects politiques et militaries de la conquête parthe de la Mésopotamie, Electrum 10: 73-88.

Dąbrowa, E. (2006): The Conquests of Mithridates I and the Numismatic Evidence, Parthica 8: 37-40.

Dąbrowa, E. (2008): The Political Propaganda of the First Arsacids and its Targets: from Arsaces I to Mithradates I, Parthica 10: 19-25.

Debord, P. (2003): Le culte royal chez les Séleucides, in F. Prost (ed.), L’Orient méditerranéen de la mort d'Alexandre aux campagnes de Pompée. Cités et royaumes à l'époque hellénistique, Rennes-Toulouse: 281-308.

Del Monte, G.F. (1997): Testi dalla Babilonia Ellenistica, vol. I: Testi Cronografici, Pisa-Roma.

Diakonoff, I.M., Livshits, V.A. (2001): Corpus Inscriptionum Iranicarum, Part II, vol. 2: Parthian Economic Documents from Nisa; Texts I: by I.M. Diakonoff \& V.A. Livshits, London.

Drijvers, J.W. (1999): Ammianus Marcellinus' Image of Arsaces and Early Parthian History, in J.W. Drijvers \& D. Hunt (eds.), The Late Roman World and its Historian. Interpreting Ammianus Marcellinus, London-New York: 193-206.

Gariboldi, A. (2004): Royal ideological patterns between Seleucid and Parthian coins: the case of $\Theta \varepsilon o \pi \alpha ́ \tau \omega \rho$, in R. Rollinger \& Chr. Ulf (eds.), Commerce and Monetary Systems in the Ancient World: Means of Transmission and Cultural Interaction, (Proceedings of the Fifth Annual Symposium of the Assyrian and Babylonian Intellectual Heritage Project held in Innsbruck, Austria, October $3^{\text {rd }}-8^{\text {th }}$ 2002), Stuttgart: 366-384.

Gaslain, J. (2005): Le bachlik d'Arsace I ${ }^{\text {er }}$ ou la representation du nomade-roi, Bulletin of Parthian and Mixed Oriental Studies 1: 9-30.

Gaslain, J. (2009): A propos d'Arsace I ${ }^{\mathrm{er}}$, Electrum 15: 27-39.

Habicht, Chr. (1956): Gottmenschentum und Griechische Städte, München.

Hopkins, C. (1960/1961): A Stele from Seleucia on the Tigris, Mélanges de l'Université Saint Joseph 37: 237-246.

Invernizzi, A. (2001a): Arsacid Dynastic Art, Parthica 3: 133-157.

Invernizzi, A. (2001b): Arsacid Palaces, in I. Nielsen (ed.), The Royal Palace Institution in the First Millennium BC. Regional Development and Cultural Interchange between East and West, Athens: 295-312.

Invernizzi, A. (2004): Thoughts on Parthian Nisa, Parthica 6: 133-143.

Invernizzi, A., Lippolis, C. (eds.) (2008): Nisa Partica. Ricerche nel complesso monumentale arsacide 1990-2006, (Centro Ricerche Archeologiche e Scavi di Torino per il Medio Oriente e l'Asia. Missione in Turkmenia - I), Firenze.

Karras-Klapproth, M. (1988): Prosopographische Studien zur Geschichte des Partherreiches auf der Grundlage antiker literarischer Überlieferung, Bonn.

Linssen, M.J.H. (2004): The Cults of Uruk and Babylon. The Temple Ritual Texts as Evidence for Hellenistic Cults Practices, Leiden-Boston.

Lippolis, C. (2002): L'ancienne Nisa. La fortresse de Mithridate, Dossiers d'Archéologie 271: 42-45.

Lippolis, C. (2006): Les recherches italiennes sur l'Ancienne Nisa, Dossiers d'Archeologie 317: 58-65.

Lippolis, C. (2009): Notes on the Iranian Traditions in the Architecture of Parthian Nisa, Electrum 15: 53-66.

Luschey, H. (1974): Bisutun. Geschichte und Forschungsgeschichte, AA: 114-149.

Pfeiffer, S. (2008): Herrscher- und Dynastiekulte im Ptolemäerreich. Systematik und Einordnung der Kultformen, München.

Muccioli, F. (2009): Il problema del culto del sovrano nella regalità arsacide: appunti per una discussione, Electrum 15: 83-104.

Pilipko, V.N. (1996): Staraja Nisa. Zdanie s kvadratnym zalom, Moskva.

Pilipko, V.N. (2000): Old Nisa. The problem of interpretation [in Rus.], Vestnik Drevnej Istorii 2000 (1): 99-112.

Pilipko, V.N. (2006): Nisa-Mihrdartkirt: une site exceptionnel de la culture parthe, Dossiers d'Archeologie 317: 52-57.

Pilipko, V.N. (2007): Some results of archaeological investigations at Old Nisa [in Rus.], Rossijskaja Archeologija 2007 (1): 150-158.

Pilipko, V.N. (2008): The central ensemble of the fortress Mihrdatkirt. Layout and chronology, Parthica 10: 33-51.

Pirngruber, R. (2009): Seleukidischer Herrscherkult in Babylon?, forthcoming. 
Robert, L. (1963): Rev. of P.M. Fraser, Samothrace, vol. II, Part 1: The Inscriptions on Stone, New York 1960, Gnomon 35: 50-79.

Robert, L. (1967): Encore une inscription grecque de l’Iran, CRAI: 281-296.

Rtveladze, E.V. (1995): Parthia and Bactria, in A. Invernizzi (ed.), In the Land of the Gryphons. Papers on Central Asian Archaeology in Antiquity, Firenze: 181-190.

Sachs, A.J., Hunger, H. (1996): Astronomical Diaries and Related Texts from Babylonia, vol. III: Diaries from 164 B.C. to 61 B.C., Wien.

Schmitt, H.H. (2005): Herrscherkult, in H.H. Schmitt \& E. Vogt (eds.), Lexikon des Hellenismus, Wiesbaden: 443-452.

Sellwood, D. (1980): An Introduction to the Coinage of Parthia, $2^{\text {nd }}$ ed., London.

Sherwin-White, S., Kuhrt, A. (1993): From Samarkhand to Sardis. A New Approach to the Seleucid Empire, London.

Wiesehöfer, J. (1996): “King of Kings” and "Philhellên”: Kingship in Arsacid Iran, in P. Bilde (ed.)., Aspects of Hellenistic Kingship, Aarhus: 55-66.

Wiesehöfer, J. (2000): „Denn Orodes war der griechischen Sprache und Literatur nicht unkundig...“ Parther, Griechen und griechische Kultur, in R. Dittmann, B. Hrouda, U. Löw, P. Matthiae, R. Mayer-Opificius \& S. Thürwächter (eds.), Variatio Delectat. Iran und Westen. Gedenkschrift für Peter Calmeyer, Münster: 703-721.

Wolski, J. (1937): Arsaces I, założyciel państwa partyjskiego (I), Eos 38: 492-513.

Wolski, J. (1938): Arsaces I, założyciel państwa partyjskiego (II), Eos 39: 244-266.

Wolski, J. (1959): L’historicité d’Arsace I ${ }^{\text {er }}$, Historia 8: 222-238.

Wolski, J. (1974): Arsace I ${ }^{\mathrm{er}}$, fondateur de l’Etat parthe, Acta Iranica 3: 159-199. 